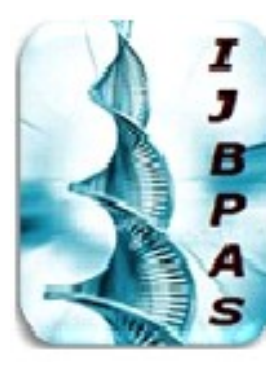

International Journal of Biology, Pharmacy and Allied Sciences (IJBPAS)

'A Bridge Betueen Caboratory and QRando'

WwW.ibpas.com

\title{
HAILEY-HAILEY- A SYSTEMATIC REVIEW
}

\section{SIVAKRISHNAN $\mathbf{S}^{1^{*}}$ AND KAVITHA $\mathbf{J}^{2}$}

1: Assistant Professor, Department of Pharmacy, FEAT, Annamalai University

2: Associate Professor, Department of Periodontia, RMDCH, Annamalai University

Annamalai Nagar, Chidambaram-608002, Tamilnadu, India

*Corresponding Author: Dr. S.Sivakrishnan: E Mail: sivacdm82@gmail.com

Received 27 ${ }^{\text {th }}$ Dec. 2020; Revised 29 $9^{\text {th }}$ Jan. 2021; Accepted $15^{\text {th }}$ Feb. 2021; Available online $1^{\text {st }}$ Oct. 2021

https://doi.org/10.31032/IJBPAS/2021/10.10.5685

\section{ABSTRACT}

Hailey-Hailey disease is also known as benign familial pemphigus. In the third or fourth decade, benign familial pemphigus usually occurs, although it can occur at any age. Then it continues to persist life-long. People of all races may be affected by it. Hailey-Hailey disease is caused by $\mathrm{ATP} 2 \mathrm{C} 1$ gene mutations and is inherited in an autosomal dominant manner, although rare cases occur occasionally without a family history. Benign familial pemphigus typically begins as a symmetrical painful erosive and crusted skin rash in the skin folds. Diagnosis may require a skin biopsy. This systematic review aimed to collect the early and recently published research articles including PubMed and Google Scholar that confirmed the epidemiology, etiology, pathogenesis, pathophysiology, clinical features, diagnosis, treatment, management and life style modifications of Hailey-Hailey disease. There is no cure for Hailey-Hailey disease. Treatment is aimed at reducing symptoms and preventing flares. Sunlight, heat, sweating and friction often aggravate the disorder.

Keywords: Hailey-Hailey disease, Desmosomes, ATP2C1 gene, Skin grafts, Botulinum toxin \section{INTRODUCTION}

Hailey-Hailey disease, first identified by the Hailey brothers in 1939, is a rare hereditary blistering skin disease [1]. The condition is characterized by red, raw, and blistered skin areas that occur most frequently in skin folds, such as the groin, armpits, throat, and under the breasts. These areas that are inflamed may become crusty or scaly and can itch and burn. With exposure to moisture (such as sweat), 
friction, and hot weather, skin conditions begin to worsen [2].

\section{Epidemiology}

Hailey-Hailey disease (HHD) is a rare disorder. Its prevalence is unclear, since many patients do not have a clear diagnosis or are not seeking care. Within families, the age of onset and clinical symptoms of HHD can differ widely. It is most common to first begin after puberty, but presentation can occur during childhood $[3,4]$. Between different ethnic groups, there is no apparent difference in prevalence.

\section{Etiology}

ATP2C1 gene mutation $[\mathbf{5}, \mathbf{6}]$, encoding the calcium pump, triggers the disease by impairing the adhesion of epidermal keratinocytes.

\section{Pathogenesis}

Pathogenesis Hailey-Hailey disease is caused by loss-of-function mutations of the adenosine triphosphate (ATP)-powered, magnesium-dependent calcium pump protein $\mathrm{hSPCA} 1$ in the $\mathrm{ATP} 2 \mathrm{C} 1$ gene at $3 q 22.1$ [7], with the function of preserving normalintracellular free calcium $(\mathrm{Ca} 2+)$ concentrations by sequestering $\mathrm{Ca} 2+$ into the Golgi apparatus [8, 9]. While rare, squamous cell carcinoma [10-12] can develop in patients with Hailey-Hailey disease.

\section{Pathophysiology}

$\checkmark$ Mutation in ATP2C1, a calcium pump that is essential for normal desmosomal protein complex function,

$\checkmark$ Dissociation of the desmosomal cadherin and E-cadherin (adherens junction associated protein) intracellular and extracellular domains

$\checkmark$ Faulty operation of the calcium pump results in desmogleins, which are calcium-dependent adherence proteins (cadherins) [13], having disorganized function.

$\checkmark$ In comparison to pemphigus vulgaris, in which autoantibodies evolve against desmosomal proteins, Hailey and Darier's diseases share similar pathogenesis.

\section{Clinical description}

Hailey-Hailey disease is seen in adulthood. It most frequently occurs at intertriginous sites (axillae, groin, and neck). There are flaccid blisters. Weepy or crusted, sharply marginalized erosions with peripheral scales are more common than intact blisters [14, 15]. Severe flare-ups may lead to infection and discharge, which may cause increased pain Pruritic/burning, often malodorous lesions. The affected areas may become particularly problematic if secondarily infected. This may be due to bacterial and/or viral (particularly the cold sore virus) infection, papular, verrucous, annular and vesiculopustular variants are rare, nikolski sign may be positive, $33 \%$ of 
cases are sporadic, healing accompanied by hyperpigmentation, but scarring is rare, longitudinal leukonychia (in $70 \%$ of patients), superinfection by candida albicans, herpes virus and staphylococcus aureus are frequent complications. cases of complication by squamous cell carcinoma have been reported and symptoms worsen during summer, often disappear during winter

\section{Diagnosis}

It is possible to confirm the diagnosis of Hailey-Hailey disease by taking a skin sample (biopsy) for analysis under a microscope. To confirm the diagnosis, a second biopsy is also taken for direct immunofluorescence. The lack of oral lesions and intercellular antibodies distinguishes familial benign pemphigus from other forms of pemphigus. Many people affected have white lines running the length of their fingernails as well. No complications are caused by these lines, but they can be useful for diagnosing HaileyHailey disease.

\section{Treatment and management}

There is no specific treatment

The treatment is based on severity and extent of the disease and is directed towards controlling symptoms. Topical medical treatment (like Triamcinolone, Hydrocortisone as $2 \%$ ointments or lotions)can alleviate the symptoms in milder forms.

* In case of severity, systemic corticosteroids like Prednisolone can be used [16].

For the prevention of secondary bacterial and fungal infections, topical antibiotics (such as erythromycin, tetracycline, clindamycin and mupirocin) and antifungal drugs (such as ketoconazole) may be prescribed [17]. It is possible to pick antibiotics on the basis of bacterial culture and susceptibility [18].

For the reduction of hyperhidrosis (excessive sweating) [19], anticholinergic drugs such as glycopyrrolate at $0.1 \mathrm{mg} / \mathrm{kg}$ may be used.

* As they inhibit sebaceous gland differentiation and abnormal keratinization [20], vitamin A derivatives such as Acitretin and Etretinate can be used.

In certain patients, medications that suppress the immune system such as Tacrolimus and Methotrexate [21-25] and astringents such as oral magnesium chloride [26, 27] can also benefit to an extent.

Physical treatments are very effective for more severe forms: CO2 laser therapy [28] (pulse or 
continuous) is often proposed as a first-line treatment. It vaporizes the affected skin; pulsed dye laser enhances the wound healing. Laser resurfacing agents that burn off the top layer of the epidermis, allowing healthy nonaffected skin to regrow in its place can also control blisters [29-34].

* Botox (botulinum toxin) is an injection which can help alongside topical treatments. It works by reducing sweating and keeping the area dry, and reduce the risk of infection [35-39].

* Photodynamic therapy with aminolevulinic acid is also successful in most of the patients [40-44].

* Skin grafts are usually necessary to repair the wounds [45].

Other techniques, such as dermabrasion [46-48] may also be required to correct the symptoms of this dermatosis.

* In many cases naltrexone, taken daily in low doses, appears to help $[49,50]$.

\section{Life Style Modifications}

Avoid triggering factors like sunburn, friction and sweating.

Sunscreens and moisturizing creams are used during the daytime.
Apply ointments to inflamed patches repetitively.

* Wash and dry the infected areas using mild soap and water once or twice daily.

Wearing clothing that is soft and loose

Avoid fabrics and other clothes that rub or irritate the areas affected.

* Stop gaining extra weight.

* To decrease friction, try decreasing body fat.

Try using 1:40 diluted aluminum acetate or vinegar to dry up oozing patches.

To reduce superficial infections, take bleach baths twice weekly [51].

\section{CONCLUSION}

Benign chronic familial pemphigus is transmitted as a dominant trait, with incomplete penetrance. Though HaileyHailey disease is not life threatening, it causes a lot of discomfort to the affected patients. At present, there is no complete cure to this disease as it is remittent. Therapeutic options are limited. The treatment is based on severity and extent of the disease and is directed towards controlling symptoms. But mostly, these are mainly directed towards providing relief to the patients rather than curing the symptoms. Topical treatments, tablet treatments and other treatments such as 
botulinum toxin, topical photodynamic therapy, dermabrasion, skin grafts and laser therapy are the several ways of helping patients with Hailey-Hailey diseases. On the other hand, life style modifications also help by providing relief to some extents. Finally, we conclude that the underlying genetic defect cannot be altered; however, treatment and life style modification does help with prevention of flare-ups and may increase the speed of healing.

\section{FINANCIAL SUPPORT}

None.

\section{CONFLICT OF INTEREST}

All authors declare that there is no conflict of interest.

\section{AUTHORS' CONTRIBUTIONS}

All the authors contributed equally to the paper.

\section{REFERENCES}

[1]Hailey H, Hailey H. Familial benign chronic pemphigus, Archives of Dermatology, 39, 1939, 679-685.

[2]James WD, Berger TG, Elston DM. Familial benign chronic pemphigus (Hailey-Hailey Disease). In: James WD, Berger TG, Elston DM, editors. Andrews' Diseases of the Skin, Clinical Dermatology, $10^{\text {th }}$ ed. Toronto: Elsevier Inc. 2006, 559-60.

[3]Daniel D. Palmer, M.D.; Harold O. Perry, M.D.Benign Familial Chronic Pemphigus, Archives of Dermatology, $86,1962,493-502$.
[4]Xu Z, Zhang L, Xiao Y, Li L, Lin Z, Yang Y et al., A case of Hailey-Hailey disease in an infant with a new ATP2C1 gene mutation, Pediatric Dermatology, 28, 2011, 165-168.

[5]De Aquino Paulo Filho T, deFreitas YK, da Nóbrega MT, Lima CB, Carriço BL, Silva MA, et al., Hailey-Hailey disease associated with herpetic eczema-the value of the Tzanck smear test, Dermatology Practical \& Conceptual, 4, 2014, 29-31.

[6]Van Beek N, Patsatsi A, Gupta Y, Möller S, Freitag M, Lemcke S, et al., A family with atypical Hailey-Hailey disease: Is there more to the underlying genetics than ATP2C1?, PLoS One, 10, 2015, e0121253.

[7]Hu Z, Bonifas JM, Beech J, Bench G, Shigihara T, Ogawa $\mathrm{H}$, et al., Mutations in ATP2C1, encoding a calcium pump, cause Hailey-Hailey disease, Nature Genetics, 24, 2000, 61-65.

[8]Sudbrak R, Brown J, Dobson-Stone C, S Carter, J Ramser, J White, et al. HaileyHailey disease is caused by mutations in ATP2C1 encoding a novel Ca2+ pump, Human Molecular Genetics, 9, 2000, 1131-1140.

[9]Fairclough RJ, Lonie L, Van Baelen K, Marek Haftek, Colin S Munro, Susan M Burge, etal., Hailey-Hailey disease: identification of novel mutations in ATP2C1 and effect of missense mutation 
A528P on protein expression levels, Journal

of Investigative Dermatology, 123, 2004, 67-71.

[10]Holst VA, Fair KP, Wilson BB, Patterson JW. Squamous cell carcinoma arising in Hailey-Hailey disease, Journal of the American Academy of Dermatology, 43, 2000, 368-371.

[11]Cockayne SE, Rassl DM, Thomas SE. Squamous cell carcinoma arising in Hailey-Hailey disease of the vulva, British Journal of Dermatology, 142, $2000,540-542$.

[12]Chun SI, Whang KC, Su WP. Squamous cell carcinoma arising in Hailey-Hailey disease, Journal of Cutaneous Pathology, 15, 1988, 234237.

[13] Nidhi Yadav, Bhushan Madke, Sumit Kar, Kameshwar Prasad, Nitin Gangane. Hailey-Hailey disease, Indian dermatology online journal, 7, 2016, 147-48.

[14] Burge SM. Hailey-Hailey disease: the clinical features, response to treatment and prognosis, British Journal of Dermatology, 126, 1992, 275-282.

[15] Wolf R, Oumeish OY, Parish LC. Intertriginous eruption, Clinics in Dermatology. 29, 2011, 173-179.

[16] Ikeda S, Suga Y, Ogawa H. Successful management of Hailey-Hailey disease with potent topical steroid ointment,
Journal of Dermatological Science, 5, 1993, 205-211.

[17]D'Errico A, Bonciani D, Bonciolini V, Verdelli A, Antiga E, Fabbri P, et al. Hailey-Hailey disease treated with methotrexate, Journal of Dermatological Report, 6, 2012, 49-51.

[18]Farahnik B, Blattner CM, Mortazie MB, Benjamin M Perry, William Lear, Dirk M Elston. Interventional treatments for Hailey-Hailey disease, Journal of the American Academy of Dermatology, 76, 2017, 551-558.

[19]Kaniszewska M, Rovner R, Arshanapalli A, Tung R. Oral glycopyrrolate for the treatment of Hailey-Hailey disease, JAMA Dermatology, 151, 2015, 328-329.

[20]Berger EM, Galadari HI, Gottlieb AB. Successful treatment of Hailey-Hailey disease with acitretin, Journal of drugs in dermatology, 67, 2007, 734-736.

[21]Fairris GM, White JE, Leppard BJ, Goodwin PG. Methotrexate for intractable benign familial chronic pemphigus, British Journal of Dermatology, 115, 1986, 640.

[22] Vilarinho C, Ventura F, Brito C.Methotrexate for refractory HaileyHailey disease, Journal of the European Academy of Dermatology and Venereology, 24, 2010, 106.

[23] Rabeni EJ, Cunningham NM. Effective treatment of Hailey-Hailey disease 
with topical tacrolimus, Journal of the American Academy of Dermatology, 47, 2002, 797-798.

[24]F Rocha Paris, A Fidalgo, J Baptista, L Lopes Caldas, A Ferreira. Topical tacrolimus in Hailey-Hailey disease, International journal of tissue reactions, 27, 2005, 151-154.

[25] Umar SA, Bhattacharjee P, Brodell RT. Treatment of Hailey-Hailey disease with tacrolimus ointment and clobetasol propionate foam, Journal of drugs in dermatology, 3, 2004, 200203.

[26] Barde NG, Mishra DB, Ingole SO.Oral magnesium chloride: A novel approach in the management of Hailey-Hailey disease, Indian Journal of Dermatology, Venereology and Leprology, 83, 2017, 259-262.

[27] Alessandro Borghi, Alessandro Rimessi, Sara Minghetti, Monica Corazza, Paolo Pinton, Annarosa Virgili. Efficacy of magnesium chloride in the treatment of Hailey-Hailey disease: from serendipity to evidence of its effect on intracellular $\mathrm{Ca}(2+)$ homeostasis, International Journal of Dermatology, 54, 2015, 543-548.

[28] Ortiz AE, Zachary CB. Laser therapy for Hailey-Hailey disease: Review of the literature and a case report, Dermatology Reports, 3, 2011, e28.
[29]Awadalla F, Rosenbach A. Effective treatment of Hailey-Hailey disease with a long-pulsed (5 ms) alexandrite laser,Journal of Cosmetic and Laser Therapy, 13, 2011, 191-192.

[30]Philip C. Don, Patrick S. Carney, William S. Lynch, M. Tarif zaim. Medhat O. Hassan. Carbon dioxide laserabrasion: A new approach to management of familial benign chronic pemphigus (Hailey-Hailey disease), Journal of dermatologic surgery and oncology, 13, 1987, 1187-1194.

[31]Kukova G, Homey B, Bruch-Gerharz D, Diedrichson E. Familial benign chronic pemphigus (Hailey-Hailey disease): successful treatment with carbon dioxide laser], Hautarzt, 62, 2011, 258-261.

[32] McElroy JA, Mehregan DA, Roenigk RK. Carbon dioxide laser vaporization of recalcitrant symptomatic plaques of Hailey-Hailey disease and Darier's disease, Journal of the American Academy of Dermatology, 23, 1990, 893-897.

[33] Katherine M Hunt, J Daniel Jensen, Stephanie B Walsh, Mary E Helms, Vera Y Soong, Elizabeth S Jacobson, et al. Successful treatment of refractory Hailey-Hailey disease with a 595-nm pulsed dye laser: a series of 7 cases, Journal of the American Academy of Dermatology, 72, 2015, 735-737. 
[34]Falto-Aizpurua LA, Griffith RD, Yazdani Abyaneh MA, Nouri K. Laser therapy for the treatment of HaileyHailey disease: A systematic review with focus on carbon dioxide laser resurfacing. Journal of the European Academy of Dermatology and Venereology, 29, 2015, 1045-1052.

[35]López-Ferrer A, Alomar A. Botulinum toxin A for the treatment of familial benign pemphigus, Actas DermoSifiliográficas, 103, 2012, 532-535.

[36] Koeyers WJ, Van Der Geer S, Krekels G. Botulinum toxin type $\mathrm{A}$ as an adjuvant treatment modality for extensive Hailey-Hailey disease. Journal of Dermatological Treatment, 19, 2008, 251-254.

[37] Jean-Christophe Lapiere, Alex Hirsh, Kenneth B. Gordon, Brian Cook, Augusto Montalvo. Botulinum toxin type A for the treatment of axillary Hailey-Hailey disease, Dermatologic Surgery, 26, 2000, 371-374.

[38] Giancarlo Rezende Bessa, Thaís Corsetti Grazziotin, Ana Paula Manzoni, Magda Blessmann Weber, Renan Rangel Bonamigo. HaileyHailey disease treatment with Botulinum toxin type $A$, journal Brazilian Annals of Dermatology, 85, 2010, 717-722.

[39]Bagherani N, Smoller BR. The efficacy of botulinum toxin type $\mathrm{A}$ in the treatment of Hailey-Hailey disease, Dermatology and Therapy, 29, 2016, 6-7.

[40] Yan X, Tian HQ, Wang CL, Yang BQ, $\mathrm{Wu}$ WZ. Successful Treatment of Hailey-Hailey Disease with Aminolevulinic Acid Photodynamic Therapy, Annals of Dermatology, 27, 2015, 222-223.

[41]Ricardo Ruiz-Rodriguez 1， J G Alvarez, P Jaén, A Acevedo, S Córdoba. Photodynamic therapy with 5-aminolevulinic acid for recalcitrant familial benign pemphigus (HaileyHailey disease), Journal of the American Academy of Dermatology, 47, 2002, 740-742.

[42]Montse Fernández Guarino 1, AinhoaMarquet Ryan, Antonio Harto, Bibiana Pérez-García, Jose María Arrázola, Pedro Jaén. Experience with photodynamic therapy in HaileyHailey disease, Journal of Dermatological Treatment, 19, 2008, 288-290.

[43]Lobato-Berezo A, Imbernón-Moya A, Aguilar-Martínez A. Refractory Hailey-Hailey Disease That Responded Well to Photodynamic Therapy, Actas Dermo-Sifiliográficas, 106, 2015, 852854.

[44] Alsahli M, Debu A, Girard C, et al., Is photodynamic therapy a relevant therapeutic option in refractory benign 
familial pemphigus (Hailey-Hailey

disease)? A series of eight patients,Journal of Dermatological

Treatment, 28, 2017, 678-682.

[45] Arora H, Bray FN, Cervantes J, Falto Aizpurua LA. Management of familial benign chronic pemphigus, Clinical, Cosmetic and Investigational Dermatology, 9, 2016, 281-290.

[46]LeBlanc KG Jr, Wharton JB, Sheehan DJ. (2011). Refractory Hailey-Hailey disease successfully treated with sandpaper dermabrasion, SKIN med, 9, 2011, 263-264.

[47]Hamm H, Metze D, Bröcker EB. Hailey-Hailey disease. Eradication by dermabrasion, Archives of Dermatology, 130, 1994, 1143-11149.

[48] Kirtschig G, Gieler U, Happle R. Treatment of Hailey-Hailey disease by dermabrasion, Journal of the American Academy of Dermatology, 28, 1993, 784-786.

[49] Ibrahim O1, Hogan SR1, Vij A1, Fernandez AP2, Low-Dose Naltrexone Treatment of Familial Benign Pemphigus (Hailey-Hailey Disease), JAMA Dermatolology, 153， 2017, 1015-1017.

[50]Albers LN, Arbiser JL, Feldman RJ. Treatment of Hailey-Hailey Disease with Low-Dose Naltrexone, JAMA Dermatology, 153, 2017, 1018-1020.

[51]Bhavya Sri K, A Very Brief Overview of Hailey-Hailey Disease with Various Available Treatment Options, Journal of Clinical \& Experimental Dermatology Research, 10(1), 2019, 477. 